\title{
DEVELOPMENTAL VENOUS ANOMALY SERVING AS A DRAINING VEIN OF BRAIN ARTERIOVENOUS MALFORMATION
}

\author{
Lukas Rasulić1,2, Filip Vitošević ${ }^{3}$, Krešimir Rotim ${ }^{4}$, \\ Svetlana Milošević Medenica ${ }^{3}$ and Dragoslav Nestorović ${ }^{3}$
}

\begin{abstract}
${ }^{1}$ School of Medicine, University of Belgrade, ${ }^{2}$ Clinical Department of Neurosurgery, Clinical Center of Serbia; ${ }^{3}$ Neuroradiology Department, Center for Radiology and MRI, Clinical Center of Serbia, Belgrade, Serbia;

${ }^{4}$ Clinical Department of Neurosurgery, Sestre milosrdnice University Hospital Center, and University of Applied Health Sciences, Zagreb, Croatia
\end{abstract}

\begin{abstract}
SUMMARY - Developmental venous anomalies are cerebral vascular malformations that present normal venous drainage of cerebral tissue. With increased and accessible usage of modern diagnostic tools, they are now one of the most commonly diagnosed cerebral vascular malformations. Although developmental venous anomalies are considered to be benign lesions, association with arteriovenous malformation renders malignant potential to this combined pathology. In the case presented, these malformations were clinically silent and diagnosed accidentally, so they were not treated either with surgery, endovascular surgery or radiosurgery, considering the possible complications such as venous infarction of the brain, and because there was no obvious neurologic deficit related to this pathology. The patient presents for regular neurosurgical follow up examinations and has been free from symptoms that were present on admission.
\end{abstract}

Key words: Central nervous system - vascular malformations; Intracranial arteriovenous malformations; Cerebral veins - abnormalities; Hydrocephalus; Case reports

\section{Introduction}

Developmental venous anomalies (DVAs) or previously known as venous angiomas are congenital cerebral vascular malformations (CVMs) with angiogenically mature venous elements that represent normal venous drainage of cerebral tissue ${ }^{1}$. They consist of radially presented medullary veins converging into an enlarged collector vein that opens into the superficial or deep pial veins ${ }^{2}$. Although DVAs are considered to be rare CVMs, with increased and accessible usage of modern diagnostic tools such as CT angiography (CTA), magnetic resonance imaging (MRI), magnetic

Correspondence to: Prof. Lukas Rasulic, $M D, P h D$, School of Medicine, University of Belgrade, Clinical Department of Neurosurgery, Clinical Center of Serbia, Belgrade, Serbia

E-mail: lukas.rasulic@kcs.ac.rs; lukas.rasulic@gmail.com

Received February 9, 2016, accepted March 17, 2016 resonance angiography (MRA) and digital subtraction angiography (DSA), they are now one of the most commonly diagnosed CVMs. The previously rare diagnosis of DVAs is also connected with the fact that DVAs are usually benign lesions without any signs or symptoms. If present, symptoms may be interpreted as a compressive effect on delicate and sensitive brain structures, or as intracerebral hemorrhage ${ }^{2,3}$. Symptoms can also be related to the coexistence with other vascular malformations, primarily cavernous malformations (CMs). While association with $\mathrm{CMs}$ is not uncommon, coexistence of DVAs and arteriovenous malformations (AVMs) is extremely rare ${ }^{3}$. We present a case of brain AVM associated with DVA. The patient was admitted to the hospital emergency room with a 2-year history of extremity weakness and frequent urination. After CT, CTA and DSA examinations, the diagnosis of communicative hydrocephalus and brain 
AVM associated with DVA was set. The patient was treated surgically due to hydrocephalus when the drainage system was placed. AVM associated with DVA has not been treated so far. The patient presents for regular neurosurgical follow up examinations and has been free from symptoms that were present on admission.

\section{Case Report}

A 70-year-old man presented to the hospital emergency room with symptoms of weakness, forgetfulness, and frequent urination in the past two months. Physical examination showed that the patient was well oriented, conscious, communicative, with a mild psychomotor deficit and weakness of the extremities. The patient reported arterial hypertension, heart disease and prostate disease, but without evidence of regular follow up and visiting physician for these problems.

Native computer tomography (CT) of the brain and contrast-enhanced CT of the brain were performed immediately upon admission. They showed dilated ventricular system and periventricularly on the front left side an oval, hypodense zone with central hy-
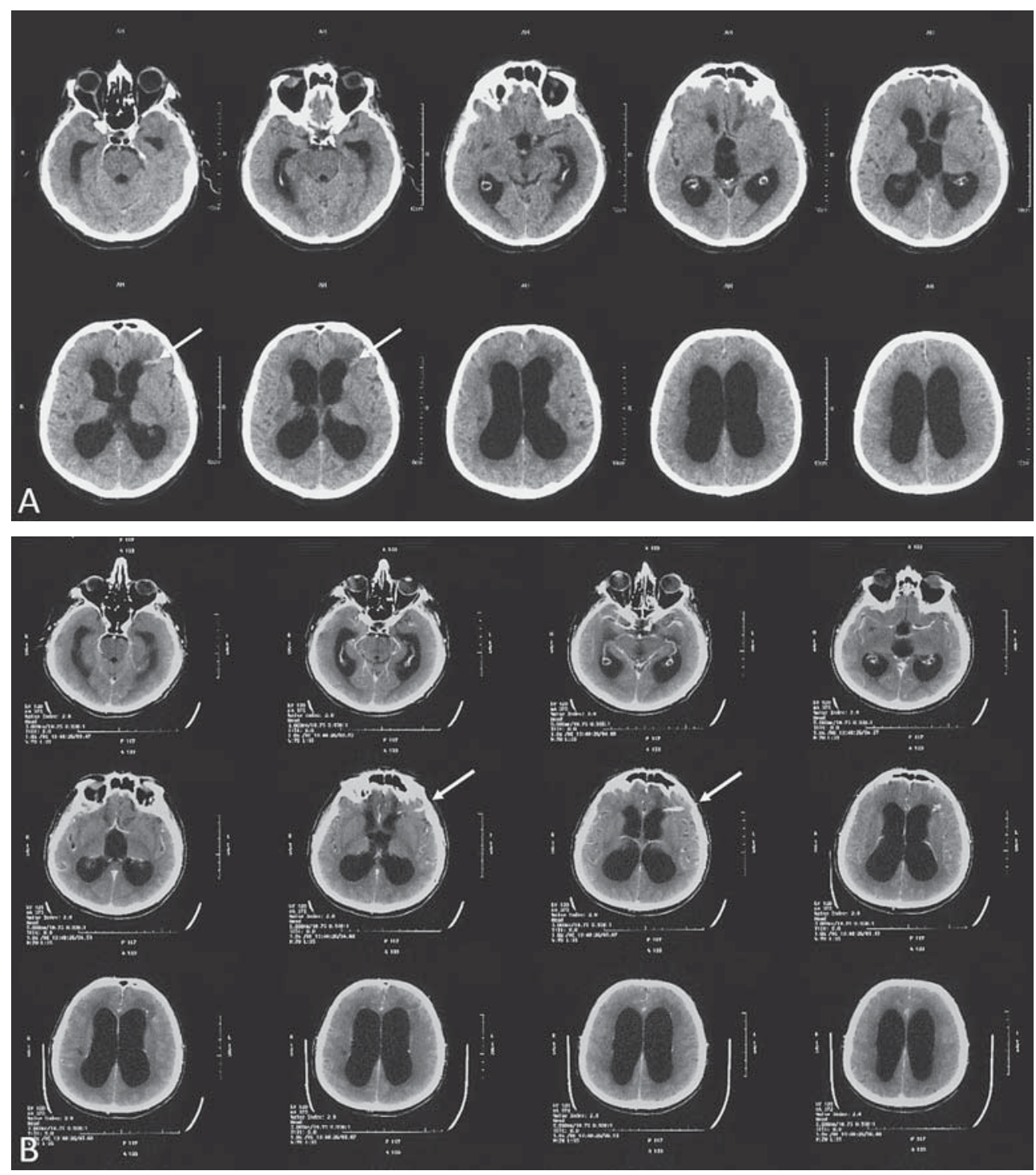

Fig. 1. Native computed tomography $(A)$ and contrast enhanced computed tomography

(B) immediately after admission to hospital emergency room (arrows show hyperdense structure). 
perdense area that became very hyperdense after application of contrast medium (Fig. 1). The diagnosis of normal pressure hydrocephalus (symptomatic hydrocephalus) was set and the patient was treated medicamentously ( $\mathrm{NaCl}$ solution, Hartmann solution, mannitol 20\%, furosemide, nifedipine, metoclopramide, metamizole-sodium, and ranitidine). CTA of brain vessels performed on the next day showed on the front left side of the brain a dilated vein that continued to the prominent cortical vein, which was further drained into the superior sagittal sinus. The radiologist suggested it could be an AVM or DVA.

The neurosurgeon concluded that the symptoms presented were not connected with CVMs, so three days after admission to the emergency room the patient was transferred to his regional medical center. Neurosurgical follow up examination was scheduled in 14 days. At discharge, the patient was feeling better
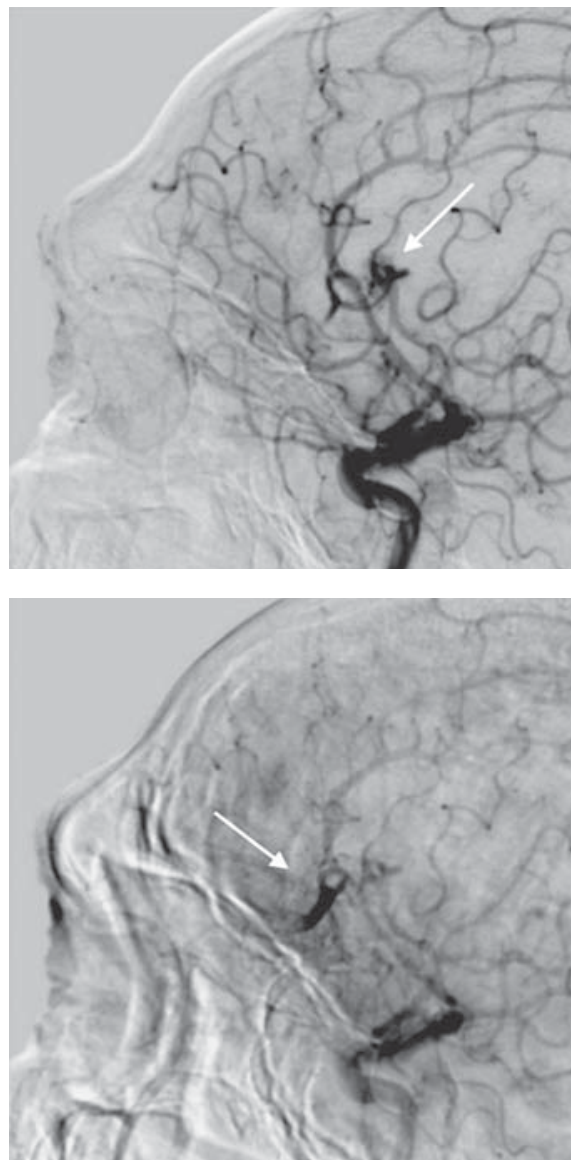

than on admission three days before, but still with weakness of the extremities. Fourteen days later at neurosurgical follow up examination, the patient was admitted to Clinical Department of Neurosurgery, so that additional diagnostic work-up could be performed and decision made on hydrocephalus treatment. On admission to the Department, the patient was welloriented, but still with weakness of the extremities and discrete paresis of the left facial nerve (central type).

One of the additional diagnostic tools was DSA of cerebral vessels, which was performed two days after admission to the Clinical Department of Neurosurgery. DSA showed on the left front side of the brain a small pial AVM, with a nidus measuring $5 \times 5 \mathrm{~mm}$, which was irrigated from perforating arteries of the M1 segment of the left medial cerebral artery (MCA), and also from one of the left MCA branches. The AVM was drained through one small vein into the ve-
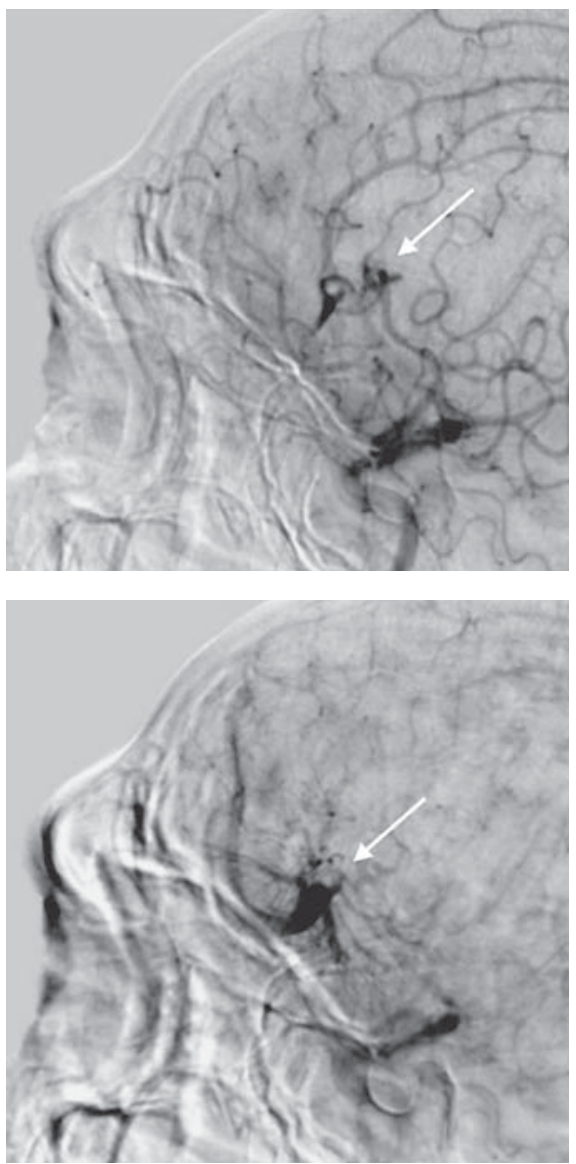

Fig. 2. Digital subtraction angiography of the left internal carotid artery showing arteriovenous anomaly in the arterial phase and developmental venous anomaly in the early venous phase (enlarged). 

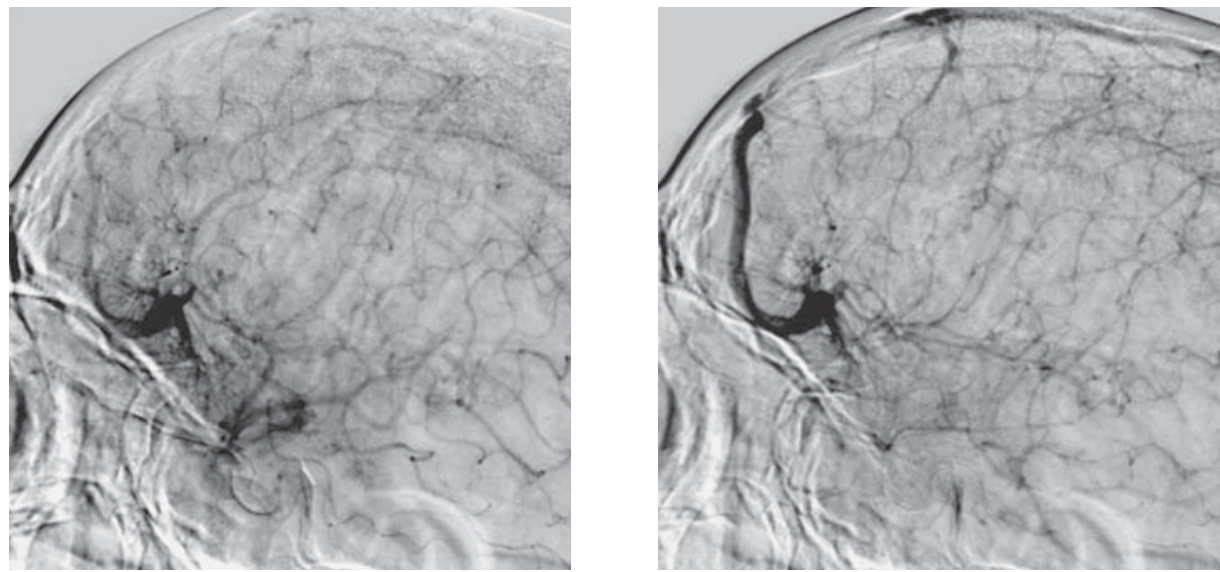

Fig. 3. Digital subtraction angiography of the left internal carotid artery showing developmental venous anomaly in the early venous phase.
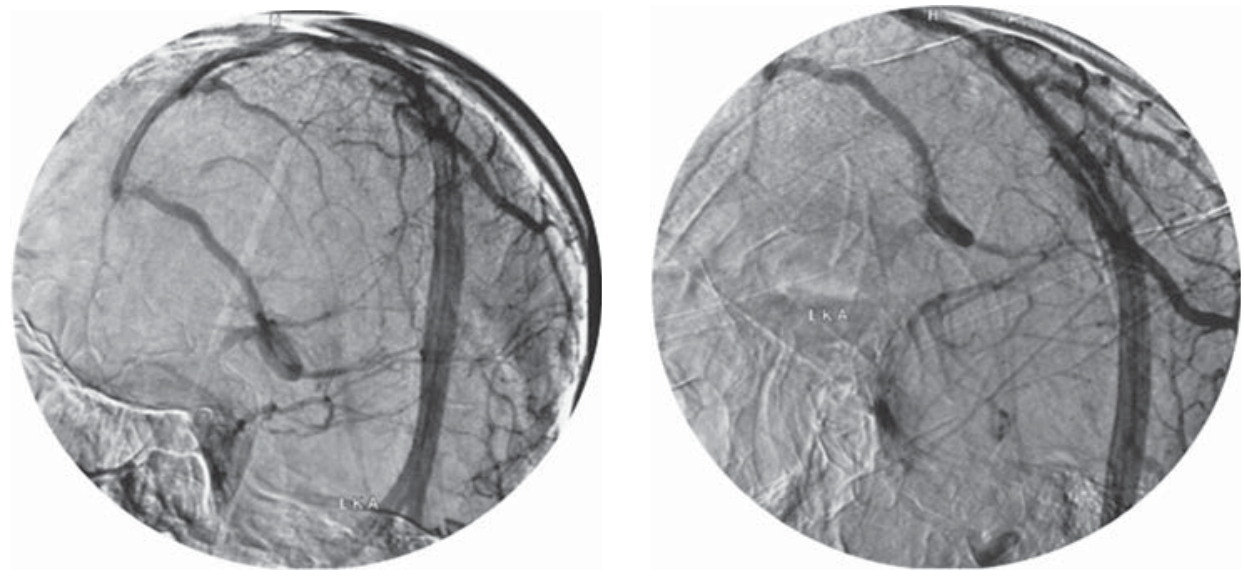

Fig. 4. Digital subtraction angiography of the left internal carotid artery showing developmental venous anomaly in the venous phase.

nous structure also located on the left front side of the brain. Radially arranged small veins were drained into this venous structure, showing a characteristic 'caput medusa' structure. The venous structure was further drained into the superior sagittal sinus of the brain. This venous structure corresponded to DVA. The AVM and DVA were only irrigated from the left internal carotid artery (ICA), without contribution from the left external carotid artery (ECA), right ICA and ECA, or vertebrobasilar arteries (Figs. 2, 3 and 4).

After preoperative preparation, endoscopic ventriculocisternostomy was performed, so that communication between third ventricle and interpeduncular cistern was created. In the early postoperative period, the patient felt better and CT of the brain performed several days after the surgery showed the first signs of hydrocephalus regression (Fig. 5).

The patient was discharged from the Clinical Department of Neurosurgery 15 days after the surgery, in much better condition than on admission, but still with extremity weakness and uncontrolled urination. Rehabilitation in the Regional Medical Center was recommended and neurosurgical follow up scheduled in three months.

Since the operation, two neurosurgical follow up examinations have been performed. The first one at three months after the surgery showed CT signs of total regression of hydrocephalus. On the second one at six months of the surgery, CT showed that hydrocephalus had resolved, with proper drainage system 


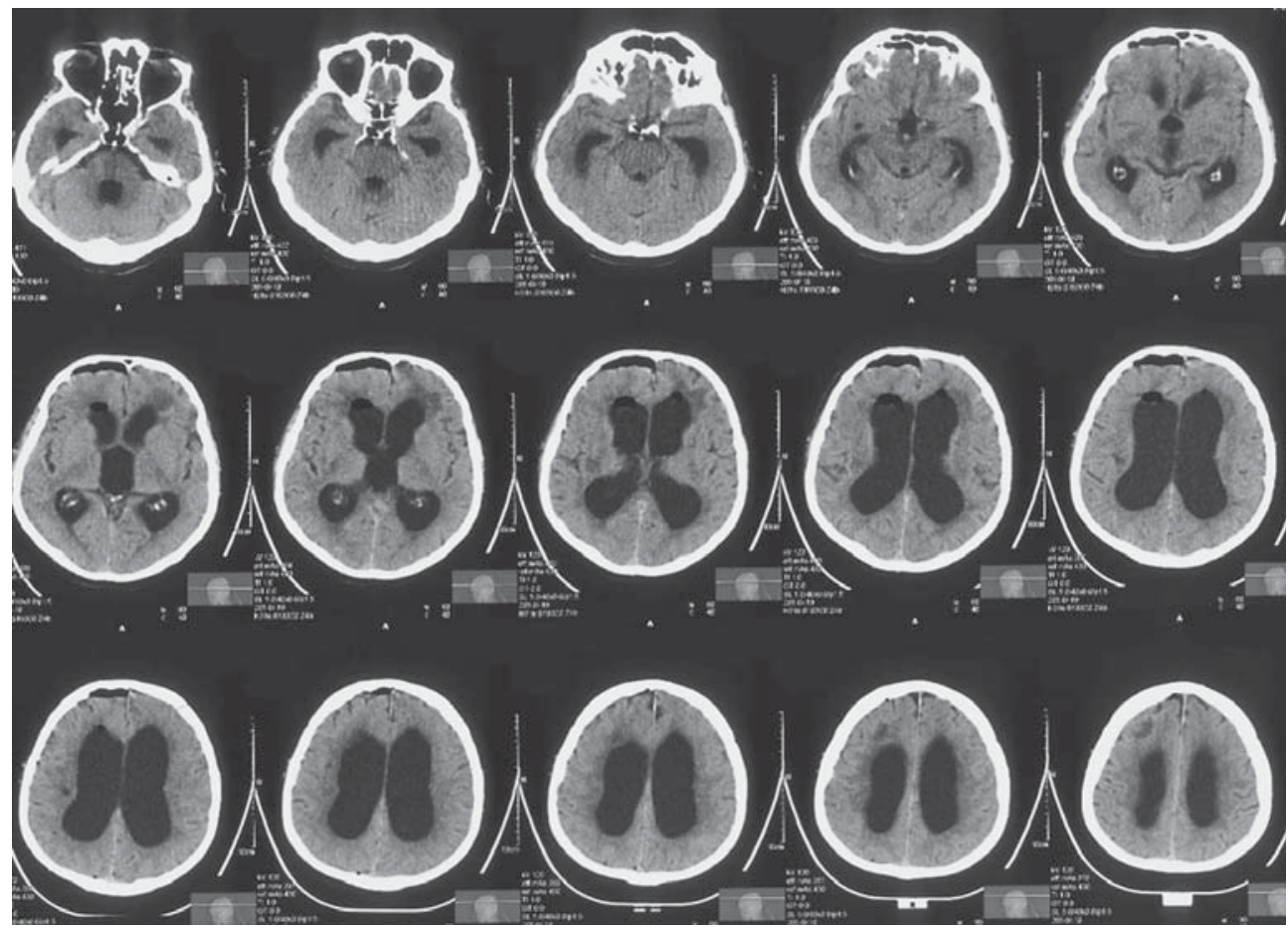

Fig. 5. Postoperative native computed tomography showing initial signs of hydrocephalus regression.

function. The patient was able to walk independently and problems with urination were resolved already at the first follow up visit. So far, DVA coexisting with AVM is clinically silent, without any signs or symptoms, and has been left untreated.

\section{Discussion}

Cerebrovascular malformations of the brain are a heterogeneous group of disorders that represent morphogenetic errors affecting arteries, capillaries, veins, or various combinations of vessels ${ }^{1}$. They are classified into AVMs, cavernous angiomas, capillary telangiectasias and DVAs. Presentation, natural history, and management approaches to CVMs depend on their type, location, size, and hemodynamic characteristics. Some CVMs such as venous or capillary malformations are almost always clinically silent and therefore usually identified accidentally on imaging or autopsy. Others, such as arteriovenous and cavernous malformations, may bleed unexpectedly and without warning ${ }^{1}$. With the increased usage of modern imaging tools, CVMs are found in up to $8 \%-10 \%$ of imaged patients, either accidentally or intentionally ${ }^{1}$.
There is also the possibility of coexistence of two or more CVMs in the same patient or within the same lesion. In these cases, association of DVA with cavernous malformation is most common, as opposed to the association of AVM and DVA, which is very rare and there are only few cases reported in the literature 3 .

Developmental venous anomalies are congenital cerebral vascular malformations with angiogenically mature venous elements and may represent anatomic variant of otherwise normal venous drainage. They are quite common and typically benign and asymptomatic. They are rarely seen on native CT scans, while contrast enhanced CT scan shows areas of enhancement radiating towards the ependymal surface of the ventricles. On MRI, they have characteristic flow void with normal adjacent brain parenchyma, while contrast enhanced MRI shows a typical 'caput medusa' appearance. On DSA, DVA shows the characteristic ' $c a-$ put medusa' form in the venous phase, presented as multiple medullary veins converging into an enlarged collector vein that further continues to a superficial or deep pial veins ${ }^{2-5}$.

Arteriovenous malformations are vascular malformations of the brain with arteriovenous shunting and 
no intervening capillary bed. They can be clinically silent or present symptoms such as headache, seizures, or neurologic deficit. They can bleed unexpectedly, which is followed by strong headache. This is especially common in cases with intranidal aneurysm or even aneurysm on feeding artery ${ }^{1,3}$. AVMs can be visualized even by native CT, although it can be normal if the AVM is small, and by contrast enhanced CT, MRI, MRA and DSA as the gold standard in diagnosis. Angiographically, they are characterized by arteriovenous shunting at the nidus level.

Cases in which AVM is in close association with DVA, and where DVA serves as a draining structure of an AVM are very rare, and there are only few cases reported in the literature ${ }^{3}$. This association results in a higher tendency to bleeding from additional hemodynamic stress on the delicate DVA structure ${ }^{6}$. They can also present with focal neurologic deficit, seizures, and brain infarctions. This may be due to compression of neural tissue by the enlarged collector vein ${ }^{7}$. They can even be clinically silent, without any signs or symptoms, as in the case presented.

The etiopathology of brain DVA associated with AVM is still unclear. It is supposed that a DVA can induce formation of a new AVM or progression of a small existing shunt because of a disturbed venous outflow $^{8}$. The best diagnostic tool for precise diagnosis of brain DVA associated with an AVM is DSA, which is still the gold standard in the diagnosis of vascular pathologies of the brain. Although sometimes enlarged draining vein can be seen even on native $\mathrm{CT}$, as it was in the case we presented, it is not always visible, and small and delicate AVM shown in our case was only visible by DSA. Contrast enhanced CT and MRI may give better visualization of pathology than native $\mathrm{CT}$, but DSA remains the best imaging tool to demonstrate mixed DVA and AVM malformations.

Treatment of brain DVA associated with AVM is challenging. A few cases we found in the literature show that this pathology treated with surgical resection and embolization ended up catastrophically, with venous infarctions. This is probably because veins that drain a venous malformation also provide drainage to normal brain tissue ${ }^{2}$. Therefore, surgical and endovascular treatment should be only considered in cases presenting with hemorrhagic stroke or serious neurologic deficit. It is considered that AVM has a greater risk of bleeding; therefore, if a patient presents with serious neurologic deficit or bleeding, only the AVM should be treated, either with surgery, endovascular surgery or radiosurgery, while avoiding venous malformation and thus the possible complications ${ }^{2,9}$.

\section{Conclusion}

Although DVA is considered a benign lesion, its association with AVM renders malignant potential to this combined pathology. In the case presented, these malformations were clinically silent and were diagnosed accidentally, so they were not treated with surgery, endovascular surgery or radiosurgery, considering the possible complications and because there was no obvious neurologic deficit related to this pathology.

\section{References}

1. Osborn AG, Salzman KL, Barkowich AJ. Diagnostic Imaging: Brain, $2^{\text {nd }}$ edition. Salt Lake City, UT: Amirsys, 2009.

2. Yanaka K, Hyodo A, Nose T. Venous malformation serving as the draining vein of an adjoining arteriovenous malformation: case report and review of the literature. Surg Neurol. 2001; 56(3):170-4.

3. Erdem E, Amole AO, Akdol MS, et al. Developmental venous anomaly coexisting with a true arteriovenous malformation: a rare clinical entity. J Neurointerv Surg. 2012;4(4):e19.

4. Sarwar M, McCormick WF. Intracerebral venous angioma. Case report and review. Arch Neurol. 1978;35:323-5.

5. Valvanis A, Wellauer J, Yasargil MG. The radiological diagnosis of cerebral venous angioma: cerebral angiography and computed tomography. Neuroradiology. 1983;24:193-9.

6. Fok KF, Holmin S, Alvarez H, et al. Spontaneous intracerebral hemorrhage caused by an unusual association of developmental venous anomaly and arteriovenous malformation. Interv Neuroradiol. 2016;12:113-21. Published online 2006 Jul 31. doi: 10.1177/159101990601200205

7. Pereira VM, Geibprasert S, Krings T, et al. Pathomechanisms of symptomatic developmental venous anomalies. Stroke. 2008;39: 3201-15. https://doi.org/10.1161/STROKEAHA.108.521799

8. Nussbaum ES, Heros RC, Madison MT, et al. The pathogenesis of arteriovenous malformations: insights provided by a case of multiple arteriovenous malformations developing in relation to a developmental venous anomaly. Neurosurgery. 1998;43: $347-51$.

9. Meyer B, Stang1 AP, Schramm J. Association of venous and true arteriovenous malformation: a rare entity among mixed vascular malformations of the brain. J Neurosurg. 1995;83: $141-4$. 
Sažetak

\section{RAZVOJNA VENSKA ANOMALIJA KAO DRENAŽNA VENA ARTERIOVENSKE MALFORMACIJE MOZGA}

\section{Rasulić, F. Vitošević, K. Rotim, S. Milošević Medenica i D. Nestorović}

Razvojne venske anomalije predstavljaju cerebrovaskularne malformacije koje čine vensku drenažu moždanog tkiva. S povećanom i dostupnijom upotrebom modernih dijagnostičkih postupaka one su sada među najčešće dijagnosticiranim cerebrovaskularnim malformacijama. Iako se razvojne venske anomalije smatraju benignim lezijama, udruženost $\mathrm{s}$ arteriovenskom malformacijom daje ovoj mješovitoj patologiji maligni potencijal. U slučaju koji predstavljamo ove malformacije bile su klinički nijeme i dijagnosticirane su slučajno, tako da nisu liječene kirurški, endovaskularno niti radioterapijom, imajući u vidu moguće komplikacije kao što su venski infarkti, kao i zato što nije bilo očitog neurološkog deficita povezanog s ovom patologijom. Naš bolesnik redovito dolazi na neurokirurške kontrole i sada nema simptoma koji su bili prisutni kod prijma.

Ključne riječi: Središnji živčani sustav - vaskularne anomalije; Intrakranijske arteriovenske malformacije; Moždane vene anomalije; Hidrocefalus; Prikazi slučaja 